\title{
EFEKTIVITAS PENGGUNAAN MODUL LARUTAN PENYANGGA BERBASIS DISCOVERY LEARNING TERHADAP HASIL BELAJAR SISWA KELAS XI MIA SMAN 7 PADANG
}

\author{
Yerimadesi ${ }^{1)}$, Ananda Putra ${ }^{2)}$, Ririanti ${ }^{3)}$ \\ ${ }^{1)}$ Staf Pengajar Jurusan Kimia, FMIPA Universitas Negeri Padang \\ ${ }^{2}$ Staf Pengajar Jurusan Kimia, FMIPA Universitas Negeri Padang \\ ${ }^{2)}$ Mahasiswa Pendidikan Kimia Jurusan Kimia, FMIPA Universitas Negeri Padang \\ yerimadesi_74@yahoo.com
}

\begin{abstract}
Quasi experiment research with randomized control posttest group only design was carried out to determine the effectiveness of using a discovery learning based module on students learning outcome. Grade XI MIA-1 to MIA-4 students academic year 2015/2016 in SMAN 7 Padang became population of this study. Through cluster sampling technique, grade XI MIA-1 and grade XI MIA-4 were chosen as experiment and control classes respectively. The experiment class was taught using discovery learning based module in buffer solution topic while the control class was taught the same topic conventionally without the module. Research instrument used was cognitive learning outcome test with multiple choice form. Data showed that the mean test score of experiement class (78.84) was higher than that of control class (71.09). Normality and homogenity test proved that both classes were homogeneous and normally distributed. T-test, as data analysis taken, showed that t-count $(3,51)$ is bigger than t-table (1.67). Thus, it could be concluded that students' cognitive learning outcome in experiment class is significantly higher than that in control class. The use of discovery learning-based module in buffer solution topic was effective in increasing learning outcome of grade XI MIA students in SMAN 7 Padang.
\end{abstract}

Keywords : Discovery Learning, Effectiveness, Cognitive Learning Outcome, Buffer Solution,Module.

\section{PENDAHULUAN}

Kimia merupakah salah satu mata pelajaran wajib yang diajarkan di tingkat SMA/MA. Berdasarkan kurikulum 2013 untuk melaksanakan proses pembelajaran guru perlu memilih salah satu model pembelajaran (discovery learning, project based learning, atau problem based learning) sesuai karakteristik pengetahuan yang dikembangkan.

Menurut Permendikbud Nomor 59 tahun 2014 model discovery learning dapat digunakan untuk materi yang memiliki dimensi pengetahuan faktual, konseptual dan prosedural, seperti materi pokok larutan elektrolit dan non elektrolit, struktur atom, asam basa, dan larutan penyangga.

Discovery learning merupakan suatu model pembelajaran penemuan yang bertujuan untuk mengembangkan cara belajar siswa aktif. Dengan belajar penemuan, siswa belajar berpikir analisis dan mencoba memecahkan sendiri masalah yang dihadapi (Hosnan, 2014). Hal ini sesuai dengan yang dilaporkan oleh oleh Putri, dkk (2014) bahwa model pembelajaran discovery learninng efektif dalam meningkatkan keterampilan berpikir fleksibel siswa pada materi asam basa. Selanjutnya Galuh (2014) melaporkan bahwa penerapan model discovery learninng dapat meningkatkan aktivitas dan prestasi belajar siswa pada materi larutan penyangga, baik pada ranah kognitif, afektif maupun psikomotor di SMA Negeri 1 Ngemplak Tahun Pelajaran 2013/2014.

Namun berdasarkan kenyataan di lapangan guru masih mengalami kesulitan menerapkan model discovery learning. Masalah ini diantaranya disebabkan karena belum tersedianya bahan ajar yang dapat membimbing dan menuntun siswa untuk menemukan konsep atau pengetahuan baru sesuai prinsip model discovery learning. Model discovery learning menuntut proses pembelajaran berpindah dari situasi teacher dominated learning ke situasi student dominated learning, sedangkan guru berperan sebagai mediator dan fasilitator. Oleh karena itu guru dituntut untuk menyiapkan bahan ajar yang dapat menuntun siswa belajar mandiri, seperti modul (Udo, 2010). 
Modul merupakan bahan ajar cetak yang memiliki komponen terlengkap dibandingkan bahan ajar lainnya, seperti LKS, dan handout. Modul memuat semua komponen penting dari bahan ajar, yaitu: judul, petunjuk belajar, KD, informasi pendukung, latihan, tugas/langkah kerja dan penilaian (Depdiknas, 2008: 18). Selain itu modul juga dilengkapi dengan kunci jawaban lembar kegiatan, kunci lembar kerja dan kunci lembar evaluasi, sehingga dengan modul siswa dapat mengukur kemampuannya sendiri dan dapat belajar sesuai kecepatan belajarnya masing-masing. Berdasarkan karak teristik bahan ajar ini, maka modul merupakan bahan ajar yang paling sesuai dengan karakteristik model discovery learning, yaitu sama-sama digunakan untuk menuntun siswa belajar mandiri. Discovery learning

Penggunaan modul dalam pembelajaran kimia dapat meningkatkan hasil belajar siswa, seperti pada materi analisis elektrokimia (Novianti, dkk, 2014), senyawa hidrokarbon dan turunannya (Febriana, dkk, 2014), konsep mol (Sunaringtyas, dkk. 2015) dan kesetimbangan kimia (Yerimadesi, dkk. 2016). Hasil penelitian juga menunjukkan bahwa penggunaan modul juga dapat merangsang motivasi intrinsik siswa untuk belajar kimia, motivasi intrinsik siswa yang belajar kimia menggunakan modul lebih tinggi secara signifikan dibandingkan dengan pembelajaran konvensional (tanpa modul) (Vaino, dkk. 2012).

Peintegrasian sintak model discovery learning ke dalam modul diharapkan dapat membantu guru dan siswa dalam menerapkan model discovery learning dalam pembelajaran kimia di sekolah. Yerimadesi, dkk (2015), telah mengembangkan modul larutan penyangga berbasis discovery learning untuk kelas XI SMA/MA. Dari hasil penelitian diperoleh modul yang valid dan praktis untuk pembelajaran kimia SMA. Namun efektifitas modul belum dilaporkan.

Penelitian ini bertujuan untuk menentukan efektifitas penggunaan modul larutan penyangga berbasis discovery learning terhadap hasil belajar siswa kelas XI MIA di SMAN 7 Padang

\section{METODE PENELITIAN}

Penelitian ini termasuk jenis penelitian ekperimen semu (quasi experiment) dengan rancangan model penelitian randomized control posstest group only design (Tabel 1). Penelitian ini dilakukan pada semester 2 tahun ajaran
2015/2016, yaitu bulan Maret sampai April 2016 di SMAN 7 Padang. Populasi terdiri dari 4 kelas, yaitu siswa kelas XI MIA-1 sampai XI MIA-4 di SMAN 7 Padang pada tahun ajaran 2015/2016. Langkah-langkah pengambilan sampel dilakukan dengan teknik cluster sampling (Gay, 2000). Setelah dilakukan uji normalitas dan homogenitas terhadap pupulasi, diperoleh kelas XI MIA-1 dan XI MIA-4 SMAN 7 Padang yang terdistribusi normal dan homogen. Pemilihan kelas eksperimen dan kelas kontrol dilakukan secara random dan terpilih kelas XI MIA-1 sebagai kelas eksperimen dan XI MIA-4 di SMAN 7 Padang sebagai kelas kontrol.

Tabel 1. Desain Penelitian (Sugiyono, 2008)

\begin{tabular}{|c|c|c|}
\hline Sampel & Perlakuan & Tes Akhir \\
\hline Kelas Eksperimen & $\mathrm{X}_{1}$ & $\mathrm{O}_{1}$ \\
\hline Kelas Kontrol & $\mathrm{Y}_{1}$ & $\mathrm{O}_{2}$ \\
\hline
\end{tabular}

$\mathrm{X}_{1}=$ pembelajaran menggunakan modul larutan penyangga berbasis discovery learning; $\mathrm{Y}_{1}=$ pembelajaran secara konvensional (tanpa modul); $\mathrm{O}_{1}=$ tes akhir untuk kelas eksperimen; dan $\mathrm{O}_{2}=$ tes akhir untuk kelas kontrol.

Kedua kelas sampel dibelajarkan menggunakan model discovery learning. Pada akhir pembelajaran kedua kelas sampel diberikan tes. Tes yang diberikan berupa tes objektif sebanyak 25 butir soal dengan 5 pilihan jawaban. Soal tes akhir yang digunakan adalah soal yang sudah diujicobakan dan dianalisis, sehingga sudah memenuhi kriteria suatu soal yang baik, yaitu valid, reliabel, memiliki daya pembeda dan indeks kesukaran soal (Arikunto, 2009).

\section{Analisis Data}

Analisis data keterlaksanaan pembelajaran dan persepsi siswa dilakukan dengan analisis deskriptif. Data hasil belajar kognitif siswa dianalisis dengan statistik kuantitatif secara berurutan, mulai dari data perbedaan nilai kelas eksperimen dan kelas kontrol, uji normalitas, uji homogenitas dan uji hipotesis. Uji normalitas bertujuan untuk mengetahui apakah sampel terdistribusi normal atau tidak. Untuk menguji normalitas digunakan uji Liliefors (Sudjana, 2005). Uji homogenitas bertujuan untuk 
mengetahui apakah data pada kedua kelas sampel sudah mempunyai varians yang homogen atau tidak. Untuk menentukan homogenitas dilakukan uji F (Sudjana, 2005). Uji hipotesis dilakukan dengan uji $t$ menggunakan persamaan (1), karena data terdistribusi normal dan kedua kelompok homogen.

$$
\mathrm{t}=\frac{x_{1}-\bar{x}}{s \sqrt{\frac{1}{n_{1}}+\frac{1}{n_{2}}}}
$$

keterangan:

$\mathrm{x}_{1}=$ Nilai rata-rata siswa kelas eksperimen

$\mathrm{x}_{2}=$ Nilai rata-rata siswa kelas kontrol

$\mathrm{s}=$ Simpangan baku

$\mathrm{n}_{1}=$ Jumlah siswa kelas eksperimen

$\mathrm{n}_{2}=$ Jumlah siswa kelas kontrol

Untuk menghitung s digunakan persamaan (2).

$\mathrm{s}=\sqrt{\frac{\left(n_{1}-1\right) s_{1}{ }^{2}+\left(n_{2}-1\right) s_{2}{ }^{2}}{n_{1}+n_{2}-2}}$

Kriteria pengujian adalah terima Ho jika : $-t_{1-1 / 2 \alpha}$ $<\mathrm{t}<\mathrm{t}_{1-1 / 2 \alpha}$ pada taraf signifikan 0,05 (Sudjana, 2005).

\section{HASIL DAN PEMBAHASAN}

\section{Hasil}

Berdasarkan hasil dan analisis data penelitian yang telah dilaksanakan pada kedua kelas sampel yaitu kelas XI MIA-1 sebagai kelas eksperimen dan kelas XI MIA-4 sebagai kelas kontrol, maka diperoleh data hasil belajar kognitif siswa (Gambar 1).

Dari Gambar 1, terlihat bahwa perolehan hasil belajar kognitif kelas eksperimen lebih tinggi dari kelas kontrol. Untuk membuktikan apakah hasil tes kognitif kedua kelas sampel yang diperoleh pada Gambar 1 berbeda secara signifikan atau tidak, maka dilakukan uji hipotesis. Sebelum dilakukan uji hipotesis terlebih dahulu dilakukan uji normalitas dan uji homogenitas.

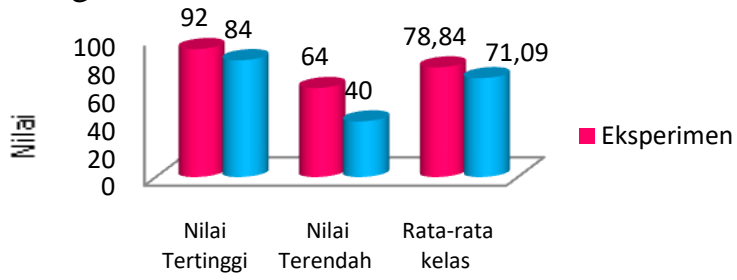

Gambar 1. Perbandingan Hasil Tes Kognitif Kelas Sampel

JEP| Volume 1| Nomor 1| Mei 2017| Page 17-23
Hasil uji normalitas, homogenitas terhadap tes akhir kelas sampel secara berturutturut dapat dilihat pada Tabel 1 dan Tabel 2.

Berdasarkan analisis data pada Tabel 1 dan 2, terlihat bahwa kedua kelas sampel terdistribusi normal dan mempunyai varians yang homogen. Oleh karena itu untuk menguji hipotesis digunakan uji $\mathrm{t}$ dan data hasil uji hipotesis ditampilkan pada Tabel 3.

Tabel 1 . Hasil Uji Normalitas terhadap Tes Akhir Kelas Sampel

\begin{tabular}{|c|c|c|c|c|c|c|}
\hline Kelas & $\mathrm{N}$ & $\mathrm{A}$ & $\mathrm{L}_{0}$ & $\mathrm{~L}_{\mathrm{t}}$ & Analisis & Distribusi \\
\hline Eksperimen & 31 & 0,05 & 0,132 & 0,159 & $\mathrm{~L}_{0}<\mathrm{L}_{\mathrm{t}}$ & Normal \\
\hline Kontrol & 31 & 0,05 & 0,098 & 0,159 & $\mathrm{~L}_{0}<\mathrm{L}_{\mathrm{t}}$ & Normal \\
\hline
\end{tabular}

Tabel 2. Hasil Uji Homogenitas terhadap Hasil Tes Akhir Kelas Sampel

\begin{tabular}{|c|c|c|c|c|c|c|}
\hline Kelas & $\mathrm{S}$ & $\mathrm{S}^{2}$ & $\mathrm{~F}_{\mathrm{h}}$ & $\mathrm{F}_{\mathrm{t}}$ & $\begin{array}{c}\text { Anali- } \\
\text { sis }\end{array}$ & $\begin{array}{c}\text { Distri- } \\
\text { busi }\end{array}$ \\
\hline $\begin{array}{c}\text { Ekspe- } \\
\text { rimen }\end{array}$ & 7,46 & 55,67 & & & & \\
\cline { 1 - 3 } $\begin{array}{c}\text { Kon- } \\
\text { trol }\end{array}$ & 9,99 & 99,96 & 3,51 & $\begin{array}{c}1,6 \\
7\end{array}$ & $\mathrm{~F}_{\mathrm{h}}<\mathrm{F}_{\mathrm{t}}$ & $\begin{array}{c}\text { Homo- } \\
\text { gen }\end{array}$ \\
\hline
\end{tabular}

Tabel 3. Hasil Uji Hipotesis terhadap Hasil Belajar kognitif kelas Sampel

\begin{tabular}{|c|c|c|c|c|c|}
\hline Kelas & $\Sigma$ Xi.Fi & $\bar{X}$ & $\mathrm{t} \mathrm{h}$ & $\mathrm{t} \mathrm{t}$ & Analisis \\
\hline $\begin{array}{c}\text { Eksperi- } \\
\text { men }\end{array}$ & 2444 & 78,84 & 3,51 & 1,67 & $\mathrm{th}>\mathrm{tt}$ \\
\hline Kontrol & 2204 & 71,09 & & \\
\hline
\end{tabular}

\section{Pembahasan}

Berdasarkan analisis data hasil belajar siswa kelas sampel dapat dilihat efektifitas penggunaan modul larutan penyangga berbasis discovery learning terhadap hasil belajar siswa kelas XI MIA di SMAN 7 Padang. Gambar 1 menunjukkan bahwa hasil belajar siswa pada kelas eksperimen lebih tinggi dari kelas kontrol.

Berdasarkan hasil uji hipotesis diperoleh $t_{h}>t_{t}$, data ini menunjukkan bahwa hasil belajar kognitif siswa kelas eksperimen lebih tinggi secara signifikan dari kelas kontrol, artinya penggunaan modul larutan penyangga berbasis discovery learning efektif terhadap hasil belajar siswa kelas XI MIA di SMAN 7 Padang. 
Efektifitas penggunaan modul disebabkan oleh beberapa hal, diantaranya karena: (1) modul merupakan bahan ajar terlengkap dibandingkan bahan ajar lainnya, seperti LKS, handout, dan lain-lain; (2) modul yang digunakan berbasis discovery learning, lembaran kegiatan siswa disusun berdasarkan sintak model ini yang terdiri dari 6 tahap, yaitu stimulation (pemberian rangsangan), problem statement (identifikasi masalah), data collection (pengumpulan data), data processing (pengolahan data), verification (pembuktian), dan generalization (menarik kesimpulan). Sintak model ini menuntun siswa untuk menemukan informasi atau pengetahuan baru; dan (3) bahan ajar dalam bentuk modul sejalan dengan model pembelajaran discovery yang dipilih, karena sama-sama untuk belajar mandiri. Berikut ini penjelasan untuk masing-masing alasan di atas.

Modul larutan penyangga berbasis discovery learning yang digunakan sudah valid dan praktis (Yerimadesi, dkk., 2015). Modul ini terdiri dari: (a) halaman depan (cover), (b) kompetensi inti, kompetensi dasar, indikator pembelajaran dan tujuan pembelajaran, (c) peta konsep, (d) petunjuk belajar atau petunjuk penggunaan modul untuk guru dan untuk siswa, (e) lembar kegiatan (LK) Siswa, (f) lembar kerja siswa (LKS), (g) kunci lembar kerja, (h) lembar evaluasi, (i) kunci evaluasi dan (i) daftar pustaka. Format penyusunan modul berdasarkan pada panduan pengembangan bahan ajar (Depdiknas, 2008) dan panduan kreatif membuat bahan ajar inovatif (Prastowo, 2011).

Modul larutan penyangga disusun berdasarkan silabus kimia kurikulum 2013. Peta konsep disusun berdasarkan tabel analisis konsep, sehingga diperoleh hubungan antara satu konsep dengan konsep yang lainnya pada materi larutan penyangga. Peta konsep disusun bertujuan untuk membimbing siswa menyatakan tingkatan dari konsep-konsep (hierarki) dan hubungan yang bermakna antara konsep-konsep yang terdapat pada materi larutan penyangga, seperti hubungan antara larutan penyangga dengan $\mathrm{pH}$, larutan penyangga asam, larutan penyangga basa, asam lemah dan basa konyugasinya, basa lemah dan asam konyugasinya, peran larutan penyangga dalam tubuh, obat-obatan dan industri.
Petunjuk belajar yang disusun telah membantu siswa dalam menggunakan modul dan membantu guru dalam membimbing siswa dalam proses pembelajaran. Siswa dapat mempelajari materi larutan penyangga dengan mudah melalui modul dan bimbingan guru dengan menerapkan model discovery learning pada kelas eksperimen. Kenyataan ini membuktikan bahwa penerapan model discovery learning sangat membutuhkan bahan ajar yang dapat menuntun siswa untuk belajar mandiri, seperti modul. Hal ini sesuai dengan yang dikemukan oleh Akinbobola, et al (2010), bahwa "dalam menerapkan pembelajaran discovery guru dituntut untuk menyediakan materi yang lengkap kepada siswa untuk belajar secara mandiri”. Materi yang lengkap dapat disajikan melalui modul.

Lembar kegiatan (LK) siswa pada modul yang disusun berdasarkan sintak model discovery learning, dapat dikerjakan dan diisi oleh siswa dengan bimbingan guru, dalam mempelajari dan memahami materi larutan penyangga secara runtun.

Pada tahap stimulation, siswa diminta untuk mengamati gambar atau tabel yang disajikan pada modul, sehingga siswa menjadi terangsang dan termotivasi untuk mempelajari materi yang akan dipelajari. Tahap ini merupa kan tahap yang berfungsi untuk menyediakan kondisi interaksi belajar yang dapat me nyumbangkan dan membantu siswa dalam mengeksplorasi bahan (Hosnan, 2014). Dengan adanya pengetahuan awal dan koneksi dengan materi yang akan dipelajari pada modul larutan penyangga berbasis discovery learning di kelas eksperimen, membuat kelas eksperimen lebih mengetahui dan mengingat pengetahuan awal yang dibutuhkan dan hubungannya dengan materi yang akan dipelajari.

Pada tahap problem statemen (identifikasi masalah), melalui modul dan bimbingan guru siswa mengidentikasi permasalahan-perma salahan yang didapatkan pada tahap stimulation, kemudian merumuskan dan menuliskan hipotesis awal pada lembaran yang disediakan di modul. Pada kelas eksperimen umumnya siswa dapat menuliskan beberapa masalah yang ditemuinya dengan mempelajari modul bagian stimulation dan menuliskan hipotesis awal pada kolom yang telah disediakan pada modul. Tahap ini berlangsung lebih terarah, walaupun masih ada beberapa siswa yang belum mengisi dengan benar. 
Pada tahap data collection (pengumpulan data), siswa menggali dan mengumpulkan informasi dengan berbagai cara yaitu, melakukan pecobaan/praktikum, mengamati objek/kejadian dan membaca sumber lain untuk membuktikan hipotesis yang sudah dituliskannya pada tahap problem statement. Diantara percobaan yang dilakukan siswa adalah identifikasi larutan penyangga, pembuatan larutan penyangga asam dan basa. Berdasarkan pengamatan siswa melakukan percobaan dengan baik dan teliti serta menuliskan data yang diperoleh pada lembar pengamatan yang disediakan di modul. Kegiatan ini membuat siswa aktif dan bersemangat, karena siswa memperoleh pengalaman belajar secara langsung, sehingga membuat pembelajaran menjadi bermakna dan bertahan lama dipikiran siswa. Pada tahap ini siswa bereksplorasi dengan cara berseksperimen (praktikum) dan mencermati literatur yang terdapat pada modul untuk membuktikan kebenaran dari hipotesis yang telah dibuat. Hal ini sesuai dengan yang dikemukakan (Hosnan, 2014), bahwa tahap data collection merupakan tahap eksplorasi, guru memberikan kesempatan kepada para siswa untuk mengumpulkan informasi yang relevan sebanyak-banyaknya untuk membuktikan benar atau tidaknya hipotesis awal.

Tahap data processing (pengolahan data), merupakan tahap pengkodean (coding/kategorisasi) yang berfungsi sebagai pembentukan konsep dan generalisasi (Hosnan, 2014). Pada tahap ini siswa pada kelas eksperimen mengerjakan soal-soal yang ada pada modul, soal-soal tersebut disusun berdasarkan kepada hierarki materi larutan penyangga yang dimulai dari pengetahuan faktual, sehingga siswa dituntun untuk menemukan pengetahuan atau konsep baru sesuai tujuan pembelajaran. Pada tahap ini hanya sedikit siswa yang kesulitan dalam menjawab soal. Hal ini berbanding terbalik dengan kelas kontrol, siswa masih kesulitan dalam menjawab soal, sehingga sering meminta penjelasan lebih lanjut dari guru. Hal ini terjadi kemungkinan karena pada kelas kontrol belum tersedia soal seperti pada modul, sehingga siswa tidak dapat dituntun dengan baik untuk menemukan konsep atau informasi baru.

Pada tahap verification (pembuktian), siswa memeriksa secara cermat untuk membuktikan benar atau tidaknya hipotesis yang ditetapkan dengan temuan alternatif, dihubungkan dengan hasil data yang telah diolah (Permendikbud no 59 tahun 2014). Pada kelas eksperimen siswa menuliskan kembali hipotesis awal dan membuktikan kebenarannya berdasar kan informasi yang sudah diperoleh pada tahap data collection dan data processing. Pada tahap ini guru mengkonfirmasi jawaban siswa. Berdasarkan pengamatan pada tahap verification ini, siswa kelas eksperimen dapat membuktikan hipotesis awal yang telah ditulisnya pada tahap problem statement dibandingkan dengan kelas kontrol. Pada kelas eksperimen siswa berpastisipasi secara aktif dalam menyampaikan hasil diskusi mereka, sedangkan kelas kontrol siswa kurang aktif. Hal ini terjadi karena tahapan-tahapan sebelumnya (stimulation, problem statement, data collection, data processing) pada kelas kontrol belum menuntun siswa untuk aktif dalam pembelajaran.

Tahap terakhir yaitu tahap generalization (menarik kesimpulan), merupakan tahap merumuskan prinsip-prinsip dan menarik kesimpulan dari hasil verification. Pada tahap ini siswa kelas eksperimen menuliskan kesimpulan yang telah diperoleh pada lembaran yang disediakan di modul. Siswa juga diminta untuk menyampaikan kesimpulan yang diperoleh secara lisan di kelas. Melalui tahap generalization guru memberikan penguatan dari konsep yang telah didapat oleh siswa.

Peintegrasian sintak model discovery learning pada modul larutan penyangga membuat siswa menjadi aktif, kreatif dan bersemangat dalam proses pembelajaran. Hal ini terbukti dari hasil belajar kognitif siswa di kelas eksperimen lebih tinggi secara signifikan dibandingkan dengan kelas kontrol. Data ini diperkuat dengan hasil belajar siswa yang diperoleh dengan mengisi komponen-komponen isian pada modul, yaitu Lembar Kegiatan (LK1 dan LK2) dan lembaran evaluasi (Gambar 2). 


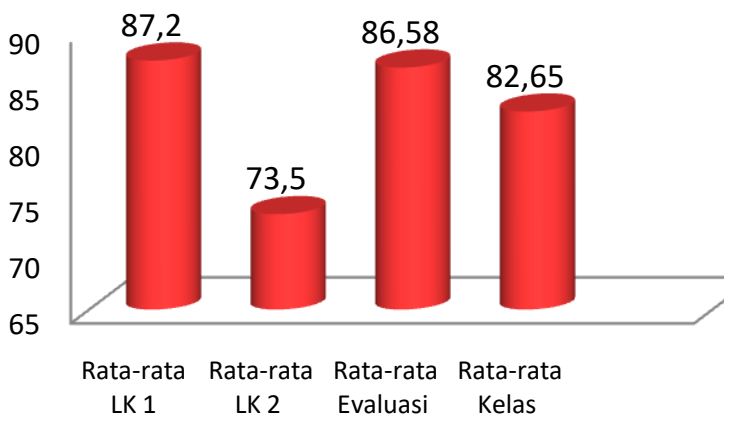

Gambar 2. Hasil Belajar Siswa Berdasarkan Analisis Jawaban pada Modul. Larutan Penyangga Berbasis Discovery Learning

Dari Gambar 2 terlihat nilai rata-rata yang diperoleh siswa dari jawaban soal-soal pada modul, yaitu nilai rata-rata LK 1 (87,2), LK 2 $(73,5)$, evaluasi $(86,58)$ dan rata-rata kelas $(82,6)$. Data ini menunjukkan bahwa nilai ratarata siswa yang diperoleh dari mengisi modul sesuai dengan nilai rata-rata hasil tes akhir siswa yang diperoleh pada kelas eksperimen (Gambar 1). Berdasarkan hasil belajar kognitif yang diperoleh siswa dengan menggunakan modul larutan penyangga berbasis discovery learning, dapat dikatakan bahwa penggunaan modul efektif terhadap hasil belajar siswa pada pembelajaran larutan penyangga kelas XI di SMAN 7 Padang. Penggunaan modul sangat mendukung peimplementasian model discovery learning dan dapat meningkatkan hasil belajar kognitif siswa dalam pembelajaran. Hal ini sesuai dengan yang dilaporkan Balim (2009), bahwa penerapan model discovery learning terbukti dapat meningkatkan hasil belajar siswa secara signifikan pada ranah kognitif. Selanjutnya Uside (2013) melaporkan bahwa model pembelajaran discovery berpengaruh terhadap ketercapaian siswa dalam meningkatkan ilmu pengetahuan.

\section{KESIMPULAN}

Berdasarkan hasil penelitian dan analisis data disimpulkan bahwa penggunaan modul larutan penyangga berbasis discovery learning efektif dalam meningkatkan hasil belajar siswa kelas XI MIA di SMAN 7 Padang. Hasil belajar siswa yang menggunakan modul larutan penyangga berbasis discovery learning lebih tinggi secara signifikan dari pada hasil belajar siswa yang menggunakan pembelajaran konvensional di kelas XI MIA SMAN 7 Padang.

\section{DAFTAR PUSTAKA}

Akinbobola, A.O. dan Afolabib. F. 2010. Constructivist Practices Through Guided Discovery Approach: The Effect on Students' Cognitive Achievement In Nigerian Senior Secondary School Physics. Eurasian J. Phys. Chem. Educ. 2(1). hlm:16-25.

Arikunto, S. 2009. Dasar- Dasar Evaluasi Pendidikan (Edisi Revisi). Jakarta: PT Bumi Aksara.

Balim, AG. 2009. The Effects of Discovery Learning on Students' Success and Inquiry Learning Skills. Egitim ArastirmalariEurasian Journal of Educational Research. No. 35. Hlm: 1-20.

Departemen Pendidikan Nasional. 2008. Pengembangan Bahan Ajar. Jakarta: Departemen Pendidikan Nasional, Direktorat Jenderal Manajemen Pendidikan Dasar dan Menengah, Direktorat Pembinaan Sekolah Menengah Atas.

Febriana, BW., Ashadi, dan M. Masykuri. 2014. Pengembangan Modul Kimia Berbasis Problem Based Learning (PBL) Pada Materi Senyawa Hidrokarbon dan Turunannya Kelas XI SMK Kesehatan Ngawi. jurnal.fkip.uns.ac.id.

Galuh, AI., Agung NCS., dan Sukardjo J.S. 2015. Penerapan Model Pembelajaran Discovery Learning untuk Meningkatkan Aktivitas dan Prestasi Belajar Pokok Bahasan Larutan Penyangga pada Siswa Kelas XI IPA Semester II SMA Negeri 1 Ngemplak Tahun Pelajaran 2013/2014. Jurnal Pendidikan Kimia (JPK). Vol. 4 No. 2. Program Studi Pendidikan Kimia. Universitas Sebelas Maret. Hal. 65-73.

Gay,R L, dkk.2000. Educational Research: Competencies for Analysis and Applications. New Jersey: Pearson.

Hosnan. 2014. Implementasi Saintifik dan Kontekstual dalam Pembelajaran Abad 21. Bogor: Ghalia Indonesia

Novianty I, Oktavia S, dan Neena Z. 2014. Efektivitas Penerapan Modul Materi Analisis Elektrokimia Berbasis Inkuiri Terbimbing Terhadap Hasil Belajar Dan 
Persepsi Siswa Kelas XI Semester 1 Kompetensi Keahlian Kimia Analisis SMKN 7 MALANG. Universitas Negeri Malang: jurnal-online.um.ac.id.

Permendikbud Tahun 2014 Nomor 59. 2014. Tentang Kurikulum 2013 Sekolah Menengah Atas/Madrasah Aliyah.

Prastowo, A. 2011. Panduan Kreatif Membuat Bahan Ajar Inovatif. Yogyakarta: DIVA press.

Putri, TP., Noor F, Ratu BR. 2014. Model Discovery Learning dalam Meningkatkan Keterampilan Berpikir Fleksibel pada Materi Asam-Basa. Jurnal Pendidikan dan Pembelajaran Kimia (JPPK) Vol. 3 No. 2. Program Studi Pendidikan Kimia FKIP Universitas Lampung.

Sudjana. 2005. Metode Statistik. Bandung: Tarsito

Sugiyono. 2008. Metode Penelitian Pendidikan : Pendekatan Kuantitatif, Kualitatif dan $R \&$ $D$. Bandung: Alfabeta.

Sunaringtyas K, Sulistyo S, Mohammad M. 2015. Pengembangan Modul Kimia Berbasis Masalah pada Materi Konsep Mol Kelas X SMA/MA Sesuai Kurikulum 2013. Jurnal Inkuiri. Vol. 4. No.2 . Hal: 36-46.

Udo, ME. 2010. Effect of Guided-Discovery, Student-Centred Demonstration and the Expository Instructional Strategies on Students' Performance in Chemistry (Pp. 389-398).An International MultiDisciplinary Journal, Ethiopia.Vol. 4 (4), Serial No. 16, October, 2010

Uside, ON. 2013. Effect Of Discovery Method On Secondary School Student's Achievement In Physics In Kenya. Asian Journal Of Social Sciences \& Humanities. Vol. 2, No. 3 hal. 357.

Vaino K, Jack H and Miia R. 2012. Stimulating students' intrinsic motivation for learning chemistry through the use of context-based learning modules. Chemistry Education Research and Practice. Vol. 13, 410419.

Yerimadesi, Bayharti, Fitri H, dan Wiwit FL. 2016. Pengembangan Modul Kesetimbangan Kimia Berbasis Pendekatan Saintifik Untuk Kelas XI SMA/MA. Journal of Saintek. Vol. 8. No. 1 Hal: 85-97.

Yerimadesi, Budhi O, dan Wilda ZF. 2015. The Development of Discovery Learning-Based Module in Buffer Solution Topic for Senior High School Instruction. Proceeding The
International Conference on Mathematics, Science, Education and Technology (ICOMSET). Chemistry Education. Hlm: 206-210. 